Iranian Journal of Cancer Care (IJCA)

Vol.1 No.3, Autumn 2020

\title{
Effect of Active Listening on Life Expectancy of Mothers who Has Children with Cancer
}

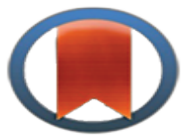

CrossMark

click for updates

\author{
Dehghani $\mathrm{F}^{1}$, Sadeghi N², Azarbarzin $\mathrm{M}^{3 *}$
}

1- Msn Student of Pediatric Nursing. Community Health Research Center, Isfahan (Khorasgan) Branch, Islamic Azad University, Isfahan, Iran.

2- Assistant Professor, Community Health Research Center, Isfahan (Khorasgan) Branch, Islamic Azad University, Isfahan,Iran.

3- Assistant. Professor Nursing and Midwifery Sciences Development Research Center, Najafabad Branch, Islamic Azad University, Najafabad, Iran.

Corresponding Author: Azarbarzin M, Assistant. Professor Nursing and Midwifery Sciences Development Research Center, Najafabad Branch, Islamic Azad University, Najafabad, Iran.

Email: azar_mehrdad@yahoo.com

Received: 18 December 2019

Accepted: 13 January 2020

\begin{abstract}
Introduction: Cancer can have negative effects on life expectancy and seems there are some ways like active listening that can improve life expectancy, therfore this research was done by aim of investigation of the Effect of active listening on life expectancy and resilience of mothers with children with cancer admitted to Sayed Alshohada Hospital in Isfahan in 2018.

Method: This study was a semi-experimental one group pre test - post test design. 50 mothers with children who had cancer and were admitted to hospital were enrolled in the study through simple method and then Subjects were randomly allocated into two groups: 26 (test) and 24 (control). The intervention group received four sessions of active listening intervention. The questionnaire used was a Snyder life expectancy questionnaire that was completed before and after the intervention. Data analysis was performed using SPSS ver 22.

Results: The results showed that, there was no significant difference between the two groups in the mean score of life expectancy before intervention $(\mathrm{p}>0.05)$. But after intervention in the experimental group was significantly more than the control group $(\mathrm{p}<0.05)$. The mean score of life expectancy in the control group was not significantly different before and after the intervention $(p>0.05)$, but in the experimental group after the intervention was significantly higher than before the intervention $(\mathrm{p}<0.05)$. Also, the mean of life expectancy score after intervention was significantly higher in the experimental group than in the control group $(\mathrm{p}<0.05)$.

Conclusion: Based on the results of this study, it can be said that active listening has an impact on the life expectancy of mothers with children with cancer and therefore it is recommended to use this intervention method in support of mothers in hospitals where children with cancer are hospitalized.
\end{abstract}

Key words: Active listening, Life Expectancy, Cancer, Mother.

\begin{tabular}{|l|l|}
\hline \multicolumn{3}{|c|}{ Access this article online } \\
\hline Website: \\
\hline www.ijca.ir
\end{tabular}




\title{
تعيين تأثير كوش دادن فعال بر اميد به زندىى مادران كودكان مبتلا به سرطان
}

\author{
فاطمه دهقانى'، نرگس صادقى '، مهرداد آذربرزين"

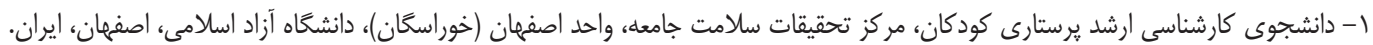

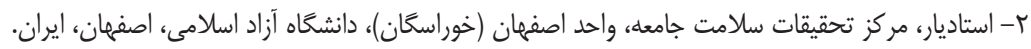

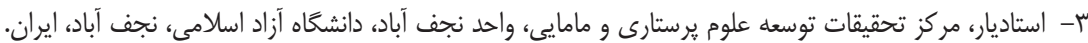

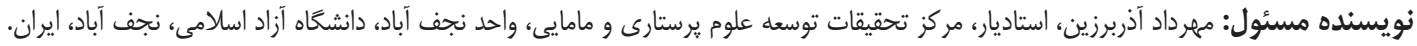 \\ ايميل: azar_mehrdad@yahoo.com

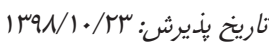

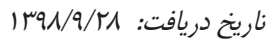

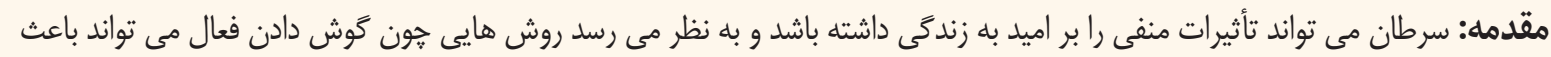

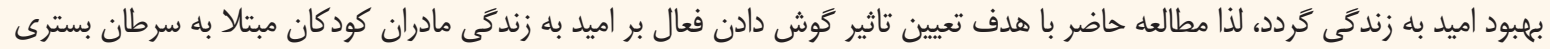
در بيمارستان سيدالشهدا اصفهان در سال لوجّ النجام كرديد.

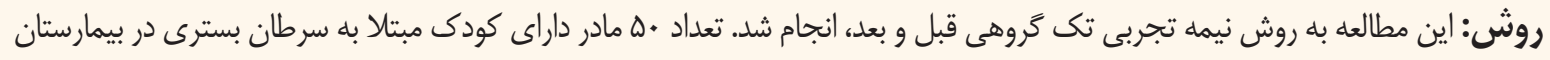

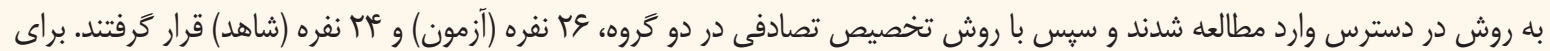

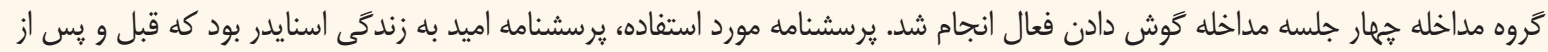

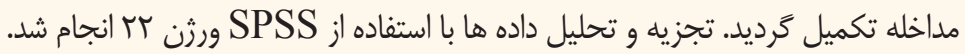

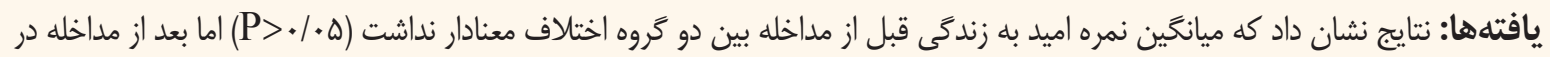

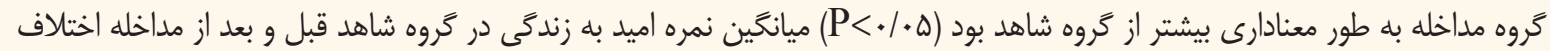

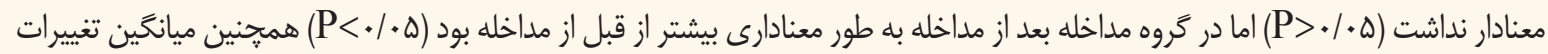

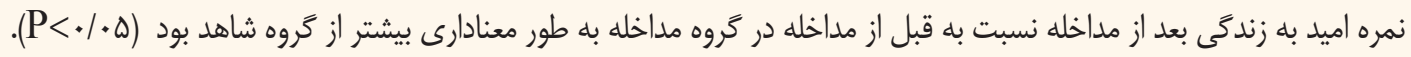

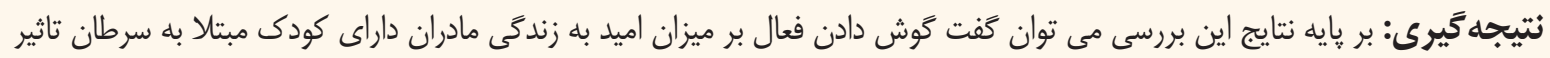

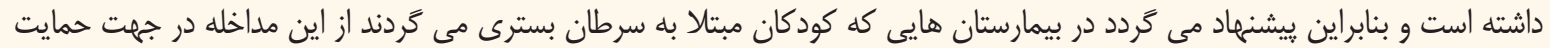

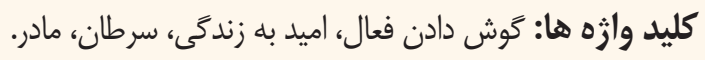

(أع)، اما طى سال هاى اخير به دليل ييشرفتهاى انجام شده در درمان

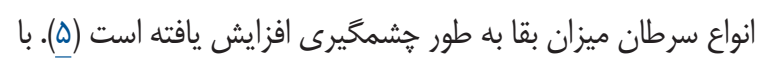
افزايش ميزان بقا در كودكان مبتلا به سرطان، متخصصان از نقش بسيار مهمم والدين در مراقبت از اين كودكان صحبت مى كنند. والدين نه تنها نقش خاصى در مراقبت از كودى حين درمان دارند، همجنين در زمان درمان نيز تماس نزديك با متخصصان مراقبت بهداشتى

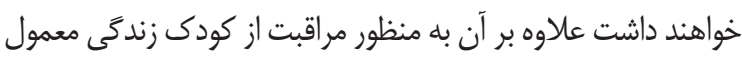
آنها و همجنين نقشهاى والدينى تغيير مى يابد بنابراين عملكرد

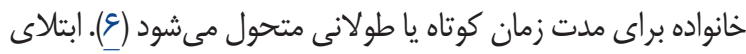

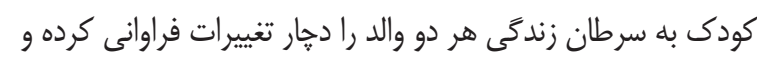

مقلدمه

سرطان وازماى كلى است كه براى معرفى تومور بدخيم و يا رشد

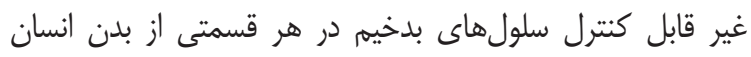

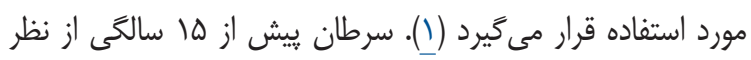

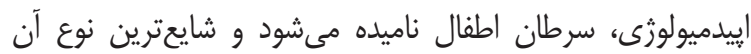
در كودكان سرطان خون است (؟َ). تشخيص سرطان در كودكان و نوجوانان يك رويداد تغيير دهنده زندگى براى كودى و خانواده محسوب مى شود و استرس فراوانى براى خانوادههاى آنان به همراه هرجند كه ميزان ابتلا كودكان به اين بيمارى در حال افزايش است 


\section{فاطمه دهقانى و همكاران}

دارد و بين تعامل يرستار - بيمار با رضايت بيماران از مراقبتهاى

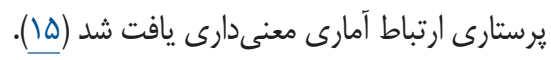

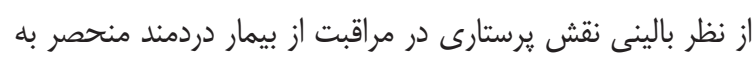

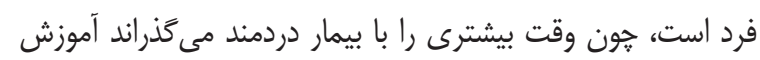

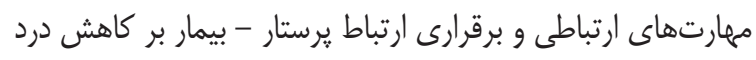

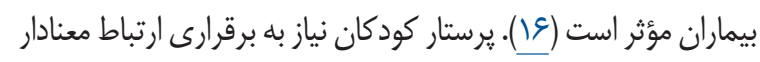

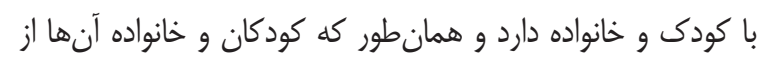

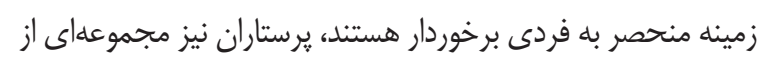
متغير هاى فردى هستند كه اين متغيرها مىتواند در برقرارى ارتباط

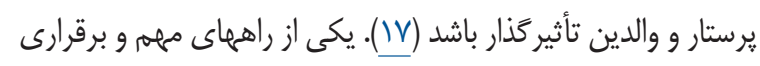
ارتباط استفاده از شنيدن فعال است (ع) وائر).

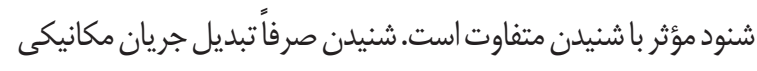
صوت به جريان الكترونيكى و فرستادن به مغز است كه به صورت

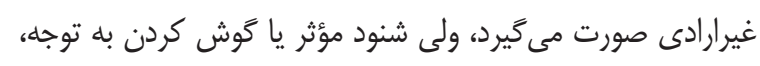

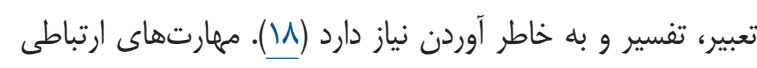

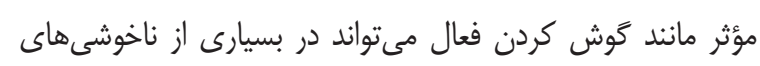

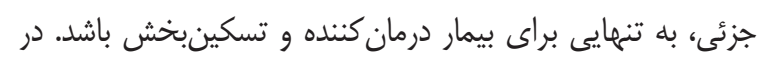

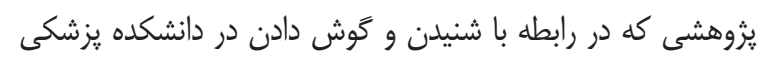
دانشخاه علوم يزشكى مشهم انجام كَرديد، اعضاى هيئت علمى بالينى

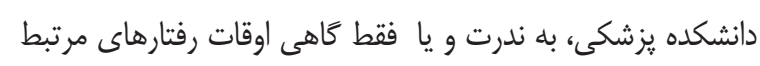

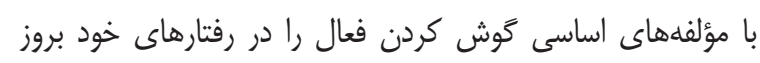

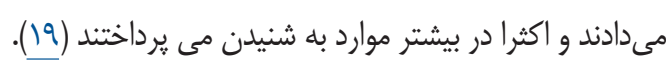

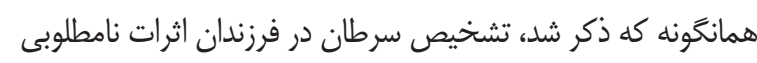

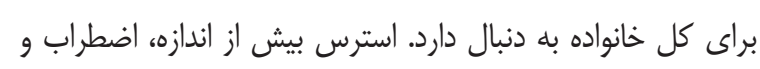

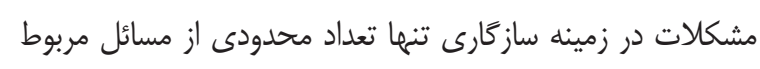

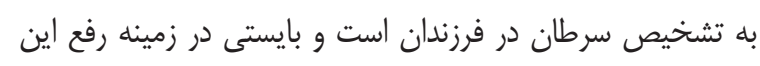

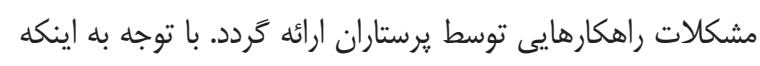

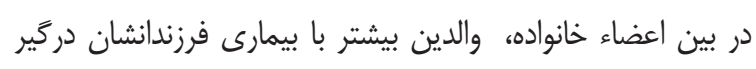

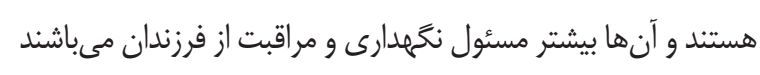

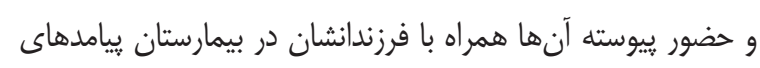

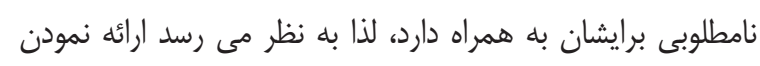

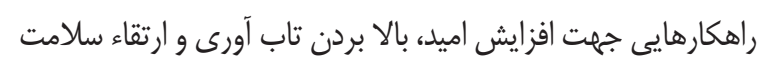

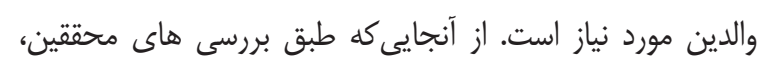

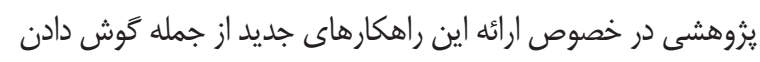

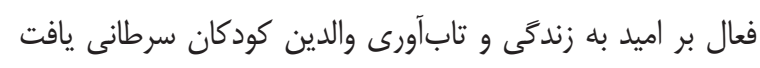

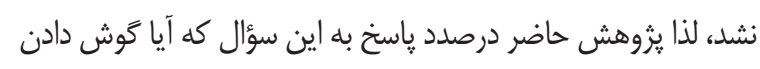

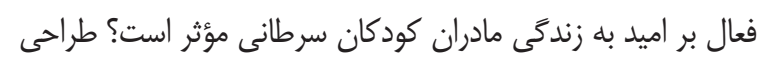

مشكلات روانى و اجتماعى فراوانى را براى آنها ايجاد مى كند (V). زمانى كه والدين با تشخيص سرطان كودكشان روبانرو مىشوند،

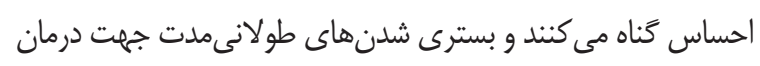

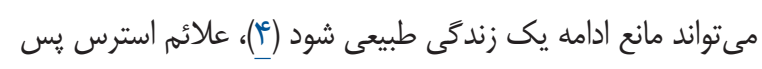

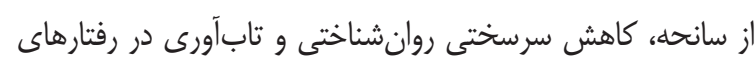

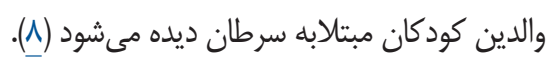

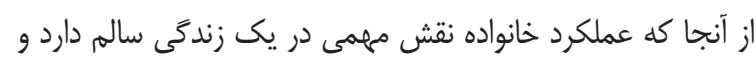

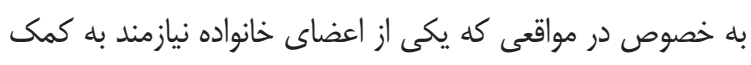

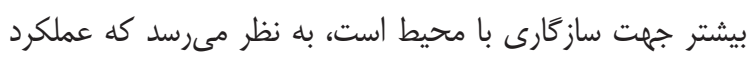

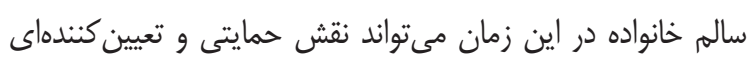

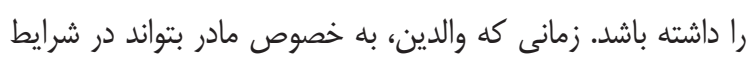
بحران احساس توانمندى كند، مىتواند كودى بيمار خود را هم مورد

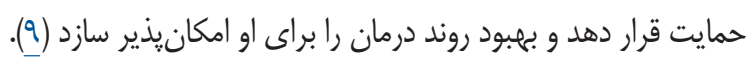

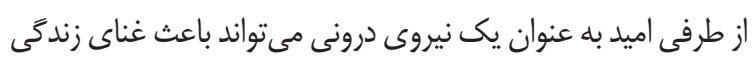

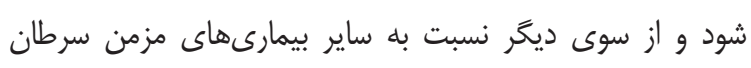

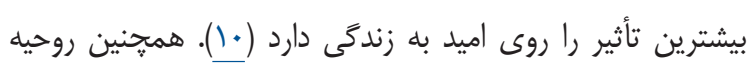

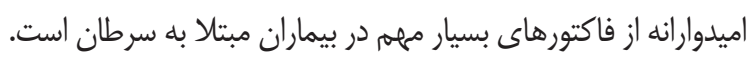

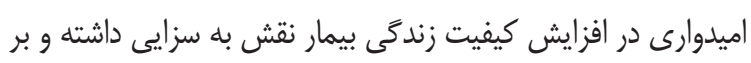
مراحل مختلف بيمارى اثركذار مىباشد (1I).

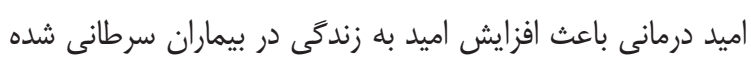

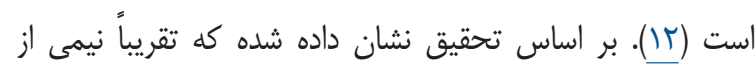

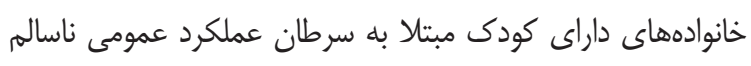

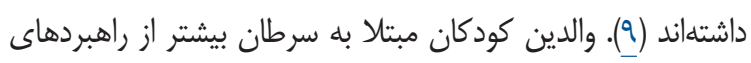

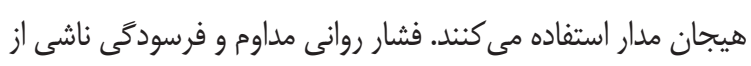

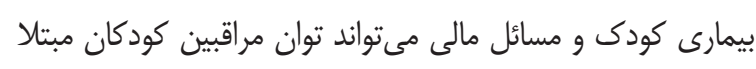

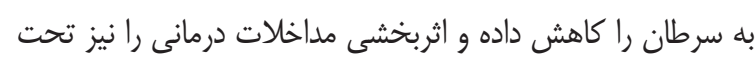

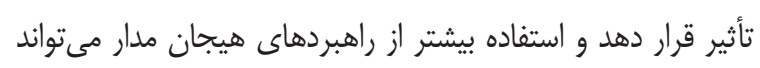
اين شرايط را تشديد نمايد (بـا).

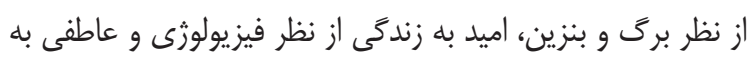
بيماران كمى مى كند تا بتوانند بحران بيمارى را تحمل كنند (أليا).

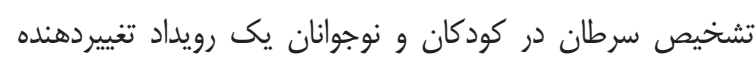

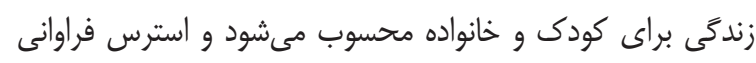
براى خانوادههاى آنان به همراه دارد (ب).

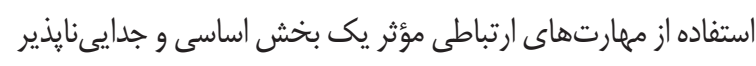

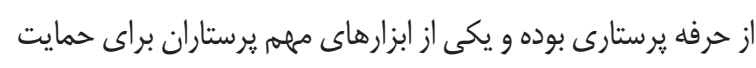

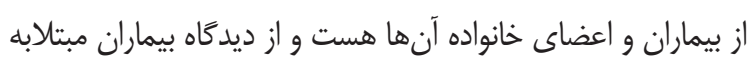

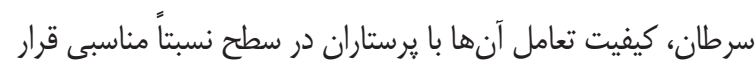


بين نمرات مقياس اميد با نمرات مقياس افكار خودكشى و رابطه

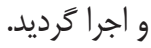

مثبت با نمرات مقياس هاى حمايت اجتماعى ادراك شده و معنا در زندگى بود. ضريب اعتبار اين مقياس با استفاده از فرمول آلفاى

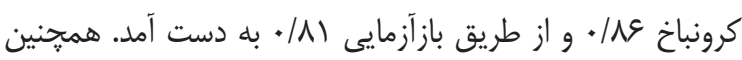
اين نويسندًان بيان مى دارند كه مقياس اميد اشنايدر براى جمعيت ايرانى از اعتبار و روايى كافى برخوردار است و در سنجش هاى روانشناختى كشور ايران قابل استفاده است و از آن مى توان بـ به عنوان ابزارى معتبر و مناسب در محيط هاى بالينى و آموزشى به منظور ارزيابى افراد و تهييه برنامه هاى درمانى و ييشخيرانه سود

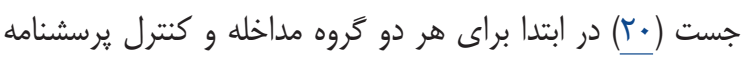
مذكور به صورت تك تك جهت ييش آزمون تكميل كرديد و سيس جهت انجام مداخله با توجه به مطالعات قبلى، جهت گرَوه مداخله جِهار جلسه گَفت و گَ به صورت فردى با محوريت گَوش دادن فعال انجام شد و در هر جلسه مادران مشكلات خودشان و

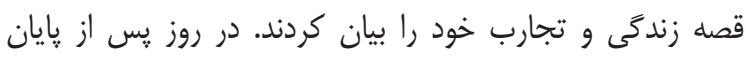
جهارمين جلسه پرسشنامه پِ آزمون توسط دو گَروه به صورت انفرادى در محيط يُوهش تكميل شد. جهت رعايت نكات اخلاقى يس از اتمام تكميل يرسشنامه ها براى مادران گروه كنترل نيز جلسات گَوش دادن فعال ارائه گَرديد. جهت تجزيه و تحليل داده ها از آزمون هاى كاى دو، من ويتنى

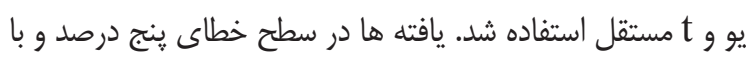
استفاده از نسخه بr نرم افزار SPSS انجام شد.

\section{يافتهها}

يافته هاى اين تحقيق بيانكَر آن است كه دامنه سنى مادران در

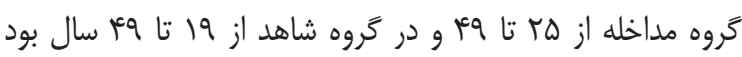
و آزمون t مستقل نشان داد كه ميانكين سن مادران و يدران، تعداد اعضاى خانواده، سن كودى مبتال، تعداد دفعات بسترى و سابقه ابتلا به بيمارى كودكان بين دو گروه اختلاف معنادار نداشت

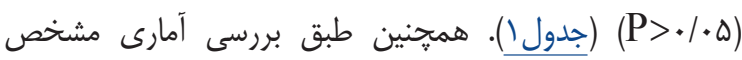
كرديد كه توزيع نمونه ها در دو كروه نرمال بوده و دو كروه قبل از انجام مداخله از نظر فاكتورهاى دموكر افيك مشابه بودند، لذا از ناز روش هاى بارامتريك جهت تجزيه و تحليل هاى آمارى استفاده

\section{روش مطالعه}

اين يُوهش، يك يزوهش نيمه تجربى قبل و بعد تك كروهى است. محيط بثوهش در اين مطالعه بيمارستان سيدالشهداء شهر اصفهان در سال Vوجا بود كه محقق با كسب مجوز از دانشخاه و مسئولين بيمارستان به محيط يزوهش وارد گرديد. جامعه آمارى يُوهش حاضر را مادران داراى كودى مبتلا به سرطان بسترى در بخش اطفال بردال

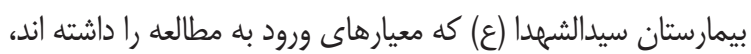
تشكيل مى داد. بر اساس محاسبه آمارى، حجم نمونه هأ نفر محاسبه كَرديد كه با توجه به احتمال ريزش •ه نفر حائز شرايط جهت شركت در اين يزوهش به طور در دسترس با استفاده از فراخوان اعلام شده

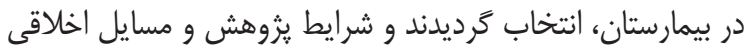
مربوط به امكان بذيرش يا رد شركت در يزوهش براى أنها توضيح

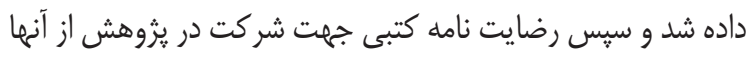
كرفته شد. سيس اين افراد با روش تخصيص تصادفى بر اساس شماره زوج و فرد كد ملى وَ نفر در كروه مداخله و أب نفر در كروه شاهد قرار داده شدند. معيارهاى ورود افراد به نمونه مطالعه شامل داشتن كودى مبتلا به سرطان بسترى در بيمارستان سيدالشهردا، آكاهى مادران از تشخيص قطعى بيمارى كودى و نقش فعال مادر

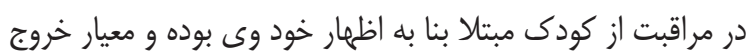
عدم تمايل مادر به ادامه يزوهش يا عدم حضور در جلسات در طى مئ يزوهش بود كه هيج مورد خروجى ديده نشد. ابزار تردآورى دادهها

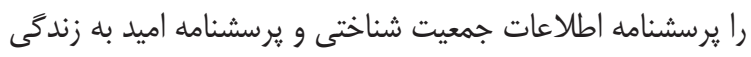

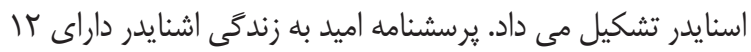
سؤال مى باشد و هدف آن ارزيابى ميزان اميد به زندَّى در افراد

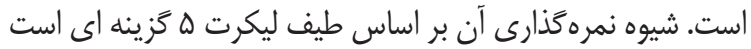

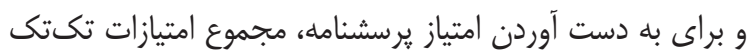
سؤالات با هم محاسبه مى كردد. امتيازات بالاتر، نشاندهنده اميد

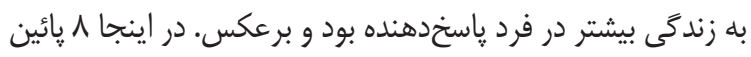
ترين نمره و عَ بالاترين نمره محسوب مى شود. روايى و يايايى يرسشنامه در مطالعات مختلف از جمله مطالعه

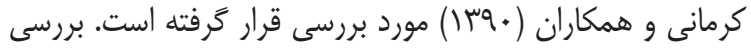
روايى سازه با استفاده از تحليل عاملى تأييدى نشان داد كه مقياس

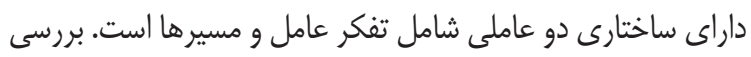

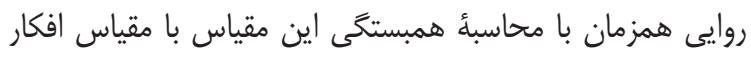

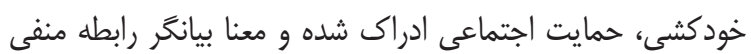




\section{فاطمه دهقانى و همكاران}

جدول ا: ميانگين متغيرهاى دموَر افيك در دو گروه كنترل و آزمون

\begin{tabular}{|c|c|c|c|c|c|c|}
\hline \multicolumn{2}{|c|}{ آزمون t مستقل } & \multicolumn{2}{|c|}{ تَروه شاهد } & \multicolumn{2}{|c|}{ تَروه مداخله } & \multirow[b]{2}{*}{ متغير } \\
\hline $\mathbf{P}$ & t & انحراف معيار & ميانكين & انحراف معيار & ميانكَين & \\
\hline . &.$/$ st $^{2}$ & $\varepsilon|\wedge|$ & 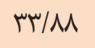 & س & $M Y / \varepsilon D$ & سن مادران (سال) \\
\hline . & $.1 / 49$ & $\varepsilon / \wedge \varepsilon$ & $r V / T f^{e}$ & $\Delta / \wedge)$ & rN/T & سن پِران (سال) \\
\hline . & $1 / T \Delta$ & $1 / 19$ & $\varphi / \cdot 1$ &.$/ 99$ & f/אॄ & تعداد اعضاى خانواده \\
\hline 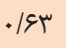 &.$/ 4 \wedge$ & $r / v q$ & $V / \& \&$ & $r / \Psi v$ & $\Lambda / \cdot \Lambda$ & سن كودكان (سال) \\
\hline.$/ 19$ & I/Tr & $r / \cdot 1$ & Q/T & 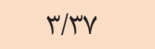 & $8 / 10$ & تعداد دفعات بسترى \\
\hline$\cdot / 0$ & $.19 \mathrm{~V}$ & $r / \kappa q$ & c/q६ & $F / \Delta \Lambda$ & $\Delta / V V^{m}$ & سابقه ابتلا به بيمارى (ماه) \\
\hline
\end{tabular}

با توجه به مساوى نبودن تعداد افراد در دو گروه از آزمون t مستقل بعد از مداخله درگروه مداخله به طور معنادارى بيشتر از گروه شاهد

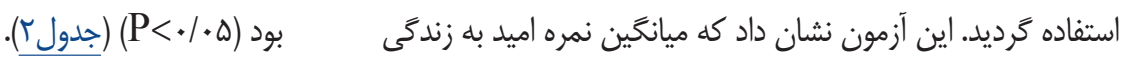

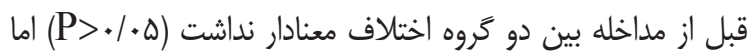
جدول ז: مقايسه ميانگين نمره اميد به زندگى قبل و بعد از مداخله بين دو كروه

\begin{tabular}{|c|c|c|c|c|c|c|}
\hline \multicolumn{2}{|c|}{ آزمون t مستقل } & \multicolumn{2}{|c|}{ كَروه شاهد } & \multicolumn{2}{|c|}{ تروه مداخله } & \multirow{2}{*}{ زمان } \\
\hline $\mathbf{P}$ & t & انحراف معيار & ميانكَين & انحراف معيار & ميانكين & \\
\hline.$/ 11$ & $1 / 8 T$ & $r / T V$ & $M F / T \Lambda$ & $r / 99$ & سות & قبل از مداخله \\
\hline$<\cdot 1 . .1$ & $\Delta / T V$ & $\Gamma / \Delta S$ & $m \varphi / l \varphi$ & $9 / \pi)$ & $F \mid / T$ & بعد از مداخله \\
\hline
\end{tabular}

آزمون t ز زوجى نشان داد كه ميانگين نمره اميد به زندگى در

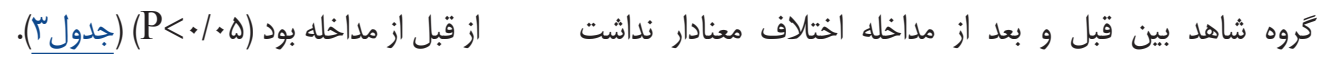
جدول "ا: مقايسه ميانگين نمره اميد به زندى در هر يك از دو گروه بين قبل و بعد از مداخله

\begin{tabular}{|c|c|c|c|c|c|c|}
\hline \multicolumn{2}{|c|}{ آزمون t زوجى } & \multicolumn{2}{|c|}{ بعد از مداخله } & \multicolumn{2}{|c|}{ قبل از مداخله } & \multirow{2}{*}{ تروه } \\
\hline $\mathbf{P}$ & $\mathbf{t}$ & انحراف معيار & ميانكَين & انحر اف معيار & ميانََين & \\
\hline$<\cdot \mid \cdot .1$ & $9 / 11$ & $g / \pi \mid$ & Fi/lr & $r / 99$ & سו/س & گروه مداخله \\
\hline .190 & .180 & $T / \Delta S$ & $m F / l g$ & $r / T V$ & TF/TA & رَروه شاهد \\
\hline
\end{tabular}

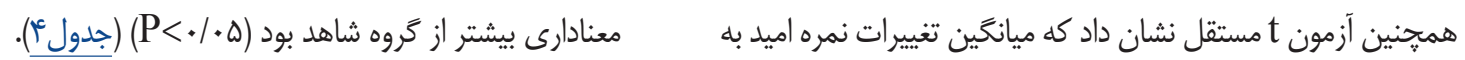

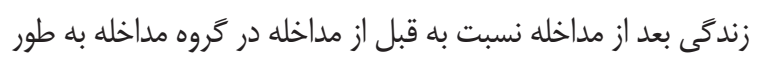

\begin{tabular}{|c|c|c|c|c|}
\hline \multicolumn{2}{|c|}{ آزمون t مستقل } & \multirow[b]{2}{*}{ انحراف معيار } & \multirow[b]{2}{*}{ ميانََين } & \multirow[b]{2}{*}{ تروه } \\
\hline $\mathbf{P}$ & $\mathbf{t}$ & & & \\
\hline$<\cdot|\cdots|$ & $V / \& q$ & $\begin{array}{l}1 / 49 \\
. / 49\end{array}$ & $\begin{array}{l}9 / 99 \\
-. / 17\end{array}$ & گرَروه مداخله \\
\hline
\end{tabular}

نتيجه يزوهش دالوندى و همكاران كه در آن تاثير برنامه القاى اميد و گَش دادن فعال بر سلامت روان سالمندان بسترى در آسايشگاه خيريه كهريزك انجام شد (Iآ) با يزوهش حاضر همسو بود ولى بايستى توجه داشت كه تحقيق مذكور در زمينه تاثير گوش دادن فعال بر سلامت روان به طور كلى بررسى شده است و با تحقيق حاضر كه اميد به زندگى را سنجيده است مى تواند متفاوت باشد اما به طور كلى شايد بتوان اذعان نمود كه گَوش دادن فعال بر يكى

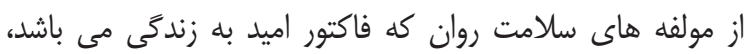
در زمينه تاثير گَوش دادن فعال بر اميد به زندكى تحقيقات زيادى

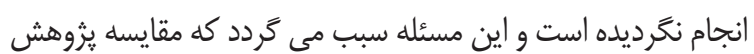
حاضر با تحقيقات ديگر كمتر قابل بررسى باشد اما با اين وجود،

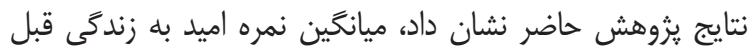

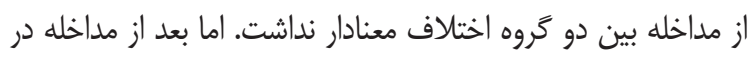

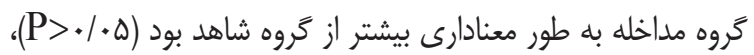




\section{تتيجه تيرى}

بر پايه نتايج اين بررسى مى توان گفت گوش دادن فعال بر ميزان اميد به زندكى مادران داراى كودى مبتلا به سرطان تاثير داشته بهان است و بنابراين يِيشنهاد مى گردد در بيمارستان هايى كه كودكان مبتلا به سرطان بسترى مى گردند از اين مداخله در جهت حمايت مادران استفاده گردد. همجنين با توجه به اين كه آموزش اين روش در سرفصلماى دروس يرستارى وجود نداشته و يرستاران كمتر با اين روش و روشهاى مشابه در افزايش اميد به زندكى و تاب آورى

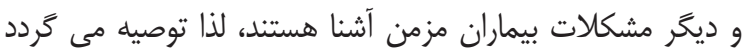
اين روشها به صورت كاركاههاى آموزش حين خدمت براى ثرسنل مئل و دانشجويان يرستارى ارائه گرديده تا افراد را قادر به استفاده مؤثر از اين روشها گَرداند و ييشنهاد مى گردد اين روشها در گروههماى ديخر بيماران مزمن و بيمارى هايى كه بر فرآيند ارتباطات خانواده تأثير روني كذار هستند نيز بررسى گردد. در يُوهش حاضر به علت ضيغ وقت محقق و كم بودن تعداد نمونه هاى در دسترس، امكان يكسان سازى نمونه ها از لحاظ ابعاد فرهنكى و تحصيلات وجود نداشت كه اين امر از محدوديتهاى خارج از دسترس يزوهشكًر بوده است كه توصيه مى گردد در تحقيقات بعدى به اين موضوع توجه گردد.

\section{تشكر و قدردانى}

اين يثوهش در قالب يايان نامه جهت اخذ درجه كارشناسى ارشد تحت راهنمايى استادان راهنما و مشاور مربوطه (نويسندگان مقاله) با مجوز و كد اخلاقى IR.IAU.KHUISF.REC1397.144 دانشگاه آزاد اسلامى واحد خور اسگان (اصفهان) انجام گرديده است محققين مراتب تشكر و قدردانى خود را از كليه مسئولين محترم اين دانشگاه و مسئولين و يرسنل محترم بيمارستان سيد الشمهدا (ع) اصفهان و تمامى مادران عزيز كه در اين يزوهش شركت نمودند، بعمل مى آورند.

\section{References}

1. Roberta Pavy R. Comprehensive Nursing Care, Revised Second Edition 2012.

2. Jadidi R, Hekmatpou D, Eghbali A, Memari F. The experiences of parents of children with leukemia: A qualitative research. Arak Medical University Journal (AMUJ). 2013; 15 (68): 2840.

3. Murphy SL, Xu J, Kochanek KD. Deaths: final data for 2010. 2013.
مى تواند مؤثر باشد.

در مطالعه باقرى زنجانى اصل منفرد و همكاران كه در آن به بررسى على اثر اميد درمانى گروهى بر تاب آورى و اميد به زندگى در بيمار ان مبتلا به سرطان پستان شهر زنجان انجام شده است يافتهها نشان داده كه اميد درمانى به شيوه گروهى سبب افزايش تابآورى و اميد به زندكى بيماران مبتلا به سرطان يستان شده است و يُوهشگًران معتقدند كه

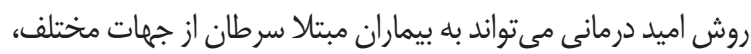
اميد به زندگى و تابأورى كمى نمايد (+1) نتايج اين تحقيق نيز با مطالعه حاضر همسو مى باشد كه در تبيين اين نتايج نيز مى توان كَت مداخلات متفاوت مانند اميد درمانى گروهى و گَوش دادن فعال مى توانند در ارتقاء سلامت روان موثر باشند و بر همين اساس شايد مايد بتوان به اين نكته كه روش هايى مثل گَوش دادن فعال مى تواند در كل بر سلامت روان و مولفه هاى آن مؤثر باشد. نتايج يزوهش حاضر نشان داد كه بين ميانگين نمره اميد به زندكى در گروه شاهد، قبل و بعد از مداخله اختلاف معنادارى وجود نداشت

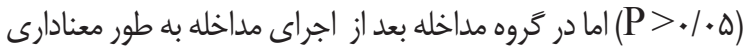

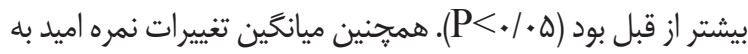

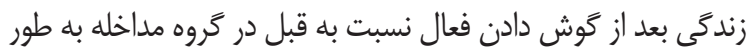

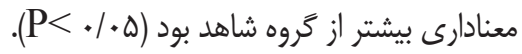
علاقبند و همكاران به بررسى رابطه بين كيفيت زندگى و اميد به

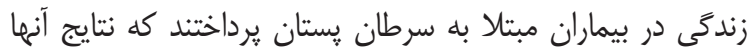

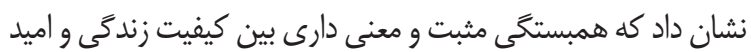
به زندگى وجود دارد همجنين بيان كرده اند كه بيمارانى كه از كيفيت زندگى خوبى برخوردارند، اميد به بهبود و ادامه زندگى نيز در آنها

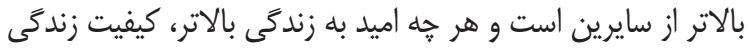
نيز مطلوب تر خواهد بود (1) كه با مطالعه حاضر همسو مى باشد. انتظار يُوهشگَران نيز برآن بود كه مداخلاتى مانند گَوش دادن فعال كه به نحوى بر سلامت روان مؤثر است، باعث ارتقاء اميد به زندگى شود كه نتايج يزوهش نيز اين موضوع را تاييد نمود.

4. Masa'Deh R, Collier J, Hall C. Parental stress when caring for a child with cancer in Jordan: a cross-sectional survey. Health and Quality of Life Outcomes. 2012; 10 (1): 88.

5. Rodríguez-Sánchez E, Pérez-Peñaranda A, Losada-Baltar A, Pérez-Arechaederra D, Gómez-Marcos MÁ, Patino-Alonso MC, et al. Relationships between quality of life and family function in caregiver. BMC family practice. 2011; 12 (1): 19 
6. Valizadeh L, Joonbakhsh F, Pashaee S. Determinants of care giving burden in parents of child with cancer at Tabriz children medical and training center. Journal of Clinical Nursing and Midwifery. 2014; 3.

7. Shamsi A, Azizzadeh Forouzi M, Iranmanesh S. Psychosocial risks among parents of children with cancer. Iranian Journal of Pediatric Nursing. 2016; 2 (3): 44 - 55.

8. Dunn MJ, Rodriguez EM, Barnwell AS, Grossenbacher JC, Vannatta K, Gerhardt CA, et al. Posttraumatic stress symptoms in parents of children with cancer within six months of diagnosis. Health Psychology. 2012; 31 (2): 176.

9. Modanloo S, Rohani C, Farahani Shirin Abadi A. Assessment of family function among parents of children with cancer. Iranian Journal of Nursing Research. 2015; 10 (1): 56 - 65.

10. Bagheri Zanjani Asl Monfared L, Entesar Foumany G. The effectiveness of group based hope-therapy on increasing resilience and hope in life expectancy in patients with breast cancer. Journal of Health Promotion Management. 2016; 5 (4): 56 - 62.

11. Alagheband M, ServatF, ZarepourF. Investigation of the Relationship between Quality of Life and Life Expectancy in Patients with Breast Cancer. Tolooebehdasht. 2016; 15 (2): 175-85.

12. Movahedi M, Movahedi Y, Farhadi A. Effect of hope therapy training on life expectancy and general health in cancer patients. Journal of Holistic Nursing And Midwifery. 2015; 25 (2): 84 - 92.

13. Ma'arefvand M, Khatamsaz Z. Coping strategies of the parents of the children with cancer. Quarterly Journal of Social Work. 2014;3 (3): 3-9.

14. Benzein EG, Berg AC. The level of and relation between hope, hopelessness and fatigue in patients and family members in palliative care. Palliative medicine. 2005;19(3):234-40.

15. Moghaddasian S, Abdollah-Zadeh F, Rahmani A, Salehain M, Firouzian A. Nurse-patient communication and its relation to satisfaction with nursing services in view point of cancer patients hospitalized in shahid ghazi hospital, Tabriz. The Journal of North Khorasan University of Medical Sciences. 2013; 5 (2): 459-66.

16. Taheri NK, Karimi MH, Dashtgard A. Effects of the nurse-patient communication skill's training on reducing pain in patients. Journal of Anesthesiology and Pain. 2015; 5 (2).

17. Sepehri Nia M, Rassouli M, Alaee Karahroudi F, Zayeri F, Zagheri Tafreshi M. Comparing perception of nurse-mother communication between nurses and mothers' hospitalized children. Quarterly Journal of Nursing Management. 2013; 2 (3): 52 - 9.

18. Shokrani R, Allamah SM, Anjomani S. A Comparative Study of Effective Hearing Skills: A Quranic, Traditional, and Civic Perspective. Two Islamic Management Scientific Journales. 2011; 20 (2): 131- 46.

19. Makarem A, Movaffaghi Z, Hosseini FS, Beiraghi N, Heshmati Nabavi F, Khaje Daluee M. Clinical Medical Teachers' Competency of Active Listening in Mashhad University of Medical Sciences. Iranian Journal of Medical Education. 2013; 12 (12): 935 - 46.

20. Kermani Z, Khodapanahi MK, Heydari M. Psychometric properties of the Hope Scale. Applied Psychology Quarterly. 2011; 5 (3 (19)): 7 - 23.

21. Dalvandi A, Memari A, Mohammadi F, Bastami A, Bastami M. Impact of Instilling Hope and Active Listening Program on Mental Health of Elderly Residents of Kahrizak Nursing Home, During Year 2015. Iranian Journal of Rehabilitation Research. 2017; 3 (3): 16 - 23. 